Vol. 22, n 1 | 2018

Varia

\title{
Obituary for J.M. (John Maurice) Beattie (1932-2017)
}

Simon Devereaux

\section{(2) OpenEdition \\ 1 Journals}

Electronic version

URL: http://journals.openedition.org/chs/2150

DOI: $10.4000 /$ chs. 2150

ISSN: 1663-4837

Publisher

Librairie Droz

Printed version

Date of publication: 31 October 2018

Number of pages: 131-133

ISSN: 1422-0857

\section{Electronic reference}

Simon Devereaux, "Obituary for J.M. (John Maurice) Beattie (1932-2017)", Crime, Histoire \& Sociétés /

Crime, History \& Societies [Online], Vol. 22, $n^{\circ} 1$ | 2018, Online since 31 December 2020, connection on

14 January 2021. URL: http://journals.openedition.org/chs/2150 ; DOI: https://doi.org/10.4000/chs.

2150

(C) Droz 


\section{Obituary for J.M. (John Maurice) Beattie (1932-2017)}

J.M. Beattie, the pioneering and preeminent historian of criminal justice in eighteenth-century England, died of cancer in Toronto on 12 July 2017 at the age of eighty-five.

John was born and raised in Newcastle. Following in the path of his elder sister, who had married an American soldier, John and his parents emigrated to the Bay Area after the war. He attended the University of San Francisco on an athletic scholarship (his induction into USF's Sports Hall of Fame in 1988 was one of many satisfying late-career honours). Initially a student of chemistry, John switched to history in his third year, a change that came naturally as the new subject seemed so "scientific" to him. That must have seemed a radical sentiment in the early 1950s! An MA in History at UC Berkeley followed, under the supervision of G.H. Guttridge, one of the era's leading historians of British politics in the age of the American Revolution. John began studying for a $\mathrm{PhD}$ at Berkeley as well, but on Guttridge's advice, he moved to Cambridge to study with the legendary J.H. Plumb. John was hired by the University of Toronto in 1961, three years before finishing his thesis. Conscious as he was of being "born at the right time," he probably exaggerated a little when he said that his interview for the job was conducted on a park bench in Lincoln's Inn Fields - and that it largely consisted of the single question: "Would you be willing to move to Toronto?"

John's thesis became his first book, The English Court in the Reign of George I (Cambridge, 1967). At the time, it might have sat comfortably on that large shelf of books produced by scholars of eighteenth-century English politics - John Brooke, Ian R. Christie, P.D.G. Thomas, to name a few - whose perspective was fundamentally shaped by the work of Sir Lewis Namier. To the present era, however, which has seen a great efflorescence in the social and cultural history of monarchy, it now seems one more pioneering study. John's abiding interest in English governance subsequently inspired him to turn his attention to those great (and, at that time, unsung) workhouses of everyday rule, the local magistrates. And this in turn led him to a subject which until then, with the singular exception of Leon Radzinowicz's four-volume History of English Criminal Law (1948-68), had received no serious scholarly analysis - crime.

John's earliest articles on the subject wrestled with what would prove to be one of its most enduring and intractable questions: to what degree might fluctuations in indictment levels accurately reflect real changes in the incidence of crime? John was more optimistic on that score than were scholars who came later. One of his articles from this era, "The Criminality of Women in Eighteenth-Century England" (Journal of Social History, 8/4 [1975], 80-116), has proven to be of particularly enduring 
value. (It also drew to Toronto a female graduate student who was surprised to discover that "J.M." Beattie was a man!) By the early 1980s, and somewhat to his own surprise - he thought he was going to write a history only of crime in Surrey John found his attention being increasingly drawn towards the subject of English punishments.

Everything came together - not only John's work to that point, but that of virtually the entire field - in Crime and the Courts in England, 1660-1800 (Princeton, 1986). One of the most widely-honoured works of scholarship ever published, it is impossible to imagine the history of English criminal law without it. The last third of this six-hundred-page book detailed a far longer history of government interest in secondary punishments than traditional "Enlightenment" accounts, focused solely upon the late eighteenth century, had ever recognized. The transformative innovation was convict transportation to America, systematized by the government in 1718 after six decades of experiments with other secondary punishments. The status of transportation as the most acceptably serious punishment next to death, and thus as a crucial relief valve in the implementation of England's famously "Bloody Code," had already been noted by several other scholars. Much more original and striking was John's recognition that transportation particularly ensured that petty thieves suffered far more serious consequences for their crimes than ever before. That was true also of the turn towards imprisonment, which John's work unexpectedly dated to the years immediately preceding both John Howard's legendary tours of British gaols and the experiments that were forced upon government by the loss of the American colonies after 1775. John's account of all these developments, which he pithily said were intended "to bring the greatest unhappiness to the greatest number of convicts" (p. 617), was more in tune with the Foucaultian trends of the 1970s and 80 s than is often appreciated.

His long-awaited follow up, Policing and Punishment in London, 1660-1750 (Oxford, 2001), deepened his account of a "long history" of secondary punishments. One of Roy Porter's final book reviews deemed this new book to be the "masterpiece" to which the earlier one had been only a "prelude" (LRB, 4 April 2002). In it, John also explored the first half-century of the Recorder's Report, the procedure whereby the central government determined whether the people condemned to death at the Old Bailey would be pardoned or hanged. (In contrast, such decisions amongst convicts in the provinces were left in the hands of the judges on their assizes circuits.) Along with the systematization of transportation, this was another indication of a post-1689 government that was more ready and willing than its predecessors to take a direct role in the management of social-economic problems. The new book's most striking contribution, perhaps, was its richly-detailed account of the many remarkable innovations undertaken in the City of London's policing arrangements during the late Stuart era, including a more reliable rota of magisterial service by the Aldermen, a more professionalized constabulary and night watch, improved street lighting, and the increased use of "thief-takers" (a sort of proto-detective force). His fourth and final book, The First English Detectives: The Bow Street Runners and the Policing of London, 1750-1840 (Oxford, 2012), was a natural sequel.

In between Crime and Policing, John also found time to advance the modern historical study of criminal defence lawyers. A particularly distinctive feature of his much-lauded article, "Scales of Justice" (Law and History Review, 9 [1991], 221-67), was its rediscovery of the life and work of the Old Bailey barrister William Garrow (1760-1840). So obvious was Garrow's dramatic appeal that he was made 
the subject of a BBC television serial, Garrow's Law (2009-11). If the show's portrayal of Garrow as an impassioned defence advocate during the infamous treason trials of 1794 was off-the-mark - in fact, Garrow was a prosecutor in those trials it nonetheless reflected that determined and witty defiance of judges, prosecutors and detectives that was so vividly evoked in John's accounts of Garrow during the 1780 s, the last of which appeared in the pages of this journal ("Garrow and the Detectives," 11/2 [2007], 5-23).

Unlike many scholars as eminent as he (and more than a few who were less so), John loved teaching. To be one of his graduate students was to feel that one had been admitted into the best of company. They fell into two generational groups, one from the 1970s and the other twenty years later. The first included such luminaries as Donna T. Andrew, P.B. Munsche and Nicholas Rogers. Yet another of John's students of that era joined that legendary coterie around E.P. Thompson which produced Albion's Fatal Tree (1975). Douglas Hay's lead-off in that volume, "Property, Authority and the Criminal Law," remains the most widely-read and influential of all works in the field. ("Not bad for an MA thesis," a proud John once remarked.) Those of us who followed later - "the Beattie Mafia," as our fellow students termed us - now work at Canadian universities ad mare usque ad mare (as the national motto would have it). Nor was John's generosity confined merely to those whom he supervised. Down to his latest years, he sustained friendships amongst his peers (far too many to be enumerated here) and continued to forge new ones with emerging young talents, inspiring gratitude, admiration and affection on an authentically global scale.

In a generation of scholars that enjoyed a status and privilege which can now only be envied, John Beattie embodied the finest qualities of unswerving collegiality. He believed - and lived his belief - that we were all united in a common endeavour of learning and communicating what had happened in the past, and that each of us was adding their own pieces to a greater canvas. He has now himself become a part of that canvas. We will not see his like again.

Simon Devereaux University of Victoria, Canada 